ECONOMICS

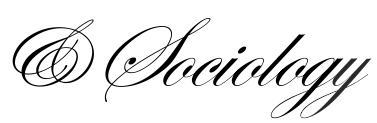

Buriak, A., Vozñáková, I., Sułkowska, J., \& Kryvych, Y. (2019). Social trust and institutional (bank) trust: Empirical evidence of interaction. Economics and Sociology, 12(4), 116-129. doi:10.14254/2071-789X.2019/12-4/7

\title{
SOCIAL TRUST AND INSTITUTIONAL (BANK) TRUST: EMPIRICAL EVIDENCE OF INTERACTION
}

\author{
Anna Buriak, \\ Sumy State University \\ Ukraine \\ Email: \\ a.buriak@uabs.sumdu.edu.ua
}

\section{Iveta Vozňáková,}

Institute of Entrepreneurship and

Marketing, University of

Entrepreneurship and Law,

Prague, Czech Republic

Email:

iveta.voznakova@seznam.cr.

\section{Joanna Sułkowska,}

University of Social Sciences, Lodr,

Poland

Email:jsulkowska@san.edu.pl

\author{
Yana Kryvych, \\ Sumy State University \\ Ukraine \\ Email: \\ y.kryvych@uabs.sumdu.edu.ua
}

Received: February, 2019

1st Revision: April, 2019

Accepted: October, 2019

DOI: $10.14254 / 2071-$

789X.2019/12-4/7

JEL Classification: A14, G21, G41
ABSTRACT. This paper analyzes the interaction between interpersonal trust (as informal rules and behavior) and trust in banks (as formal rules and institutions) as well as institutional sources of trust. Structural equation modeling and cluster analysis were applied to data from the World Values Survey extracted from the Wave 6 (2010-2014). The results of cross-sectional estimations show complementary view on interaction - a positive link between interpersonal trust and trust in banks. Using cluster method, strong impact of institutional environment (GDP per capita, Education Index, Inequality Index, Rule of Law Index) on the level of interaction has been found. The lowest level of linkages between interpersonal trust and trust in banks is associated with the worst institutional environment, the highest level of impact - with the best institutional environment.
Keywords: interpersonal trust, institutional trust, banks, structural equation modeling 


\section{Introduction}

The global financial turmoil of 2007-2008 was followed by the trust crisis - the loss of public confidence in financial markets, institutions and other related economic agents. According to the Edelman Trust Barometer, financial services were one of the least-trusted sectors globally. The issue of trust in financial system has become of high importance among regulatory authorities as well as academia. Without trust, banks would fail to perform their main transformational role in the economy - attracting deposits and other money funds and allocating them effectively. This would be leading to negative economic and social outcomes, including financial instability and well-being deterioration. Repairing trust in financial institutions requires examination and identification of all relevant trust determinants, taking into account not only traditional (like deposit insurance system, bank transparency etc.) but also psychological (behavioral) aspects like social trust (Prince, 2017). Trust (distrust) as a cultural trait and an indicator of cooperative behavior in the economy can significantly promote (inhibit) trust in financial institutions despite the enforcement of legal system, transparent bank policy or meaningful regulation (Reiersen, 2017).

Three types of trust are differentiated in literature: particularized (personal), generalized (interpersonal) and institutional (systemic). Theoretical foundation of this research concerns investigation of linkages and relationships between different types of trust - interpersonal (generalized) in the form of social trust and institutional one - in the form of trust in banks. Social scientists have analyzed correlation between generalized and limited (particularized, personal) trust explaining the impact of family ties on cooperative behavior with strangers across countries (Ermisch \& Gambetta, 2010; Alesina \& Giuliano, 2013; Lazányi et al., $2017 \mathrm{a}, \mathrm{b}$ ). However, majority of results point to the central role of generalized trust (not particularized one) in economic performance, thus making it the primary point for research. Particularized trust has not found sufficient empirical support for its relevance for economic outcomes.

Most of the related economic research focuses on the outcomes of interpersonal (generalized) social trust. It is often seen as part of the social capital concept (Fukuyama, 1995; Putnam, 1993) that stimulates the performance of public institutions (La Porta et al., 1997), economic growth by reducing transaction costs among economic actors (Zak \& Knack, 2001) and financial development (Guiso, Sapienza \& Zingales, 2008). In financial studies the question of trust in banks has received special attention through identification of sociodemographic, political, economic and individual bank factors of influence on trust in banks (Fungácová, Hasan \& Weill, 2016; van Esterik-Plasmeijer, van Raaij, 2017). Little attention has been paid to the linkages between two types of trust - of psychological nature (social trust) and of economic origin (trust in banks).

The aim of this paper is to deepen the understanding of the interaction between informal rules (social trust) and formal institutions (banks) by focusing on the sources and roots of trust. The contribution of this paper is addressing the multidimensional nature of trust while it has been neglected in the existing empirical studies in finance focusing basically on one type of trust and its effects. While the majority of recent studies have been focusing on a linear regression method to find out the mechanism of interaction between different types of trust, this paper will be using structural analysis to take into consideration the joint dynamics of development for formal institutions (banks) as well as informal ones (trust in the society). Moreover, most of the recent research has been mainly dealing with the causal mechanism between different types of trust, however, we will focus on the conditions of successful interaction between social trust and trust in banks. 


\section{Literature review}

\subsection{Interpersonal trust as relevant determinant of economic outcomes}

Despite massive support in psychological research interpersonal trust has become more common in other fields like economic studies. As it reflects psychological reasons of agent's behavior, it determines economic activity through interactions among individuals, groups and organizations in the society based on beliefs and expectations of people (Simpson, 2007; Borum, 2010).

On theoretical side, interpersonal trust means trust in other people - people outside of the family and without personal ties - and forms social capital of the country (Fukuyama, 1995, Putnam, 1993). Interpersonal trust is particularly important in modern risky societies full of social interactions characterized by high uncertainty (Abrhám \& Lžičař, 2018, Rojek, 2019). Ability to trust in other people is associated with economic performance as favors economic exchanges and resources allocation, expands possibilities of cooperation.

On empirical side, interpersonal trust is often treated as "cultural" variable to capture informal rules, values and beliefs of the certain territory and as social capital element (Alesina \& Giuliano, 2015, Kaasa, A., 2016, Tofan, 2017; Szkudlarek \& Biglieri, 2016). Most research has demonstrated strong positive correlation between interpersonal trust and main economic outcomes. Zak and Knack (2001) reveal that interpersonal trust substantially impacts economic growth by reducing transactions costs of economic actors. Algan and Cahuc (2013) point that higher level of trust positively related to income level in Europe and across US states, explaining significant part of GDP around the world. Moreover, it should be noted importance of the conditions for this positive influence (identified through control variables) like institutional quality. For example, above mentioned authors found that interpersonal trust has stronger influence in poor countries with inefficient markets and legal system. In other words, there is negative interaction between interpersonal trust and trust in institutions.

Interpersonal trust as part of social capital is considered to be important determinant in shaping financial systems and financial development (Levine \& Ross, 2005, Guiso, Sapienza \& Zingales, 2008, Njegovanovic, 2018, Prince, 2018, Kowo, Owotutu \& Adewale, 2019) have found that social trust determines behavior of economic agents on the financial market on the example of Italy regions (like investing less in cash and more in stock, using more checks etc.). Main focus of recent finance literature has been shifted on investigating linkages between trust and financial crisis of 2007-2008 as latter was famous as trust crisis which is associated with credit squeeze at financial markets, the loss of financial institutions' reputation, collapse of public confidence and trust in majority of economic institutions (Schatz \& Watson, 2011; Roth, 2009; Gros \& Roth, 2010; Sapienza \& Zingales, 2012; Vasylieva et al., 2014, 2015; Leonov et al., 2014; Naser, 2019). Untrustworthy institutions are considered to be one of the key features of last financial crisis and main reason of trust crisis caused by failures in the behavior of financial institutions like banks, regulatory authorities, governments, rating agencies (Andrushkiv et al., 2011; Gillespie \& Hurley, 2013; Tonkiss, 2009; Sapienza \& Zingales, 2012; Veggeland, 2018).

In the context of the trust role in the financial system research focus has been shifted from interpersonal trust (as informal rules and beliefs) to institutional one (formal institutions). Ensuring trust has become one of the main tasks of regulatory and governmental bodies last 10 years as financial, political and macroeconomic stability requires sufficient level of both interpersonal and institutional trust. Since that, trust and its role cannot be studied without institutions (Agnihotri et al., 2019; Kostel et al., 2017; Brychko, 2018). 


\subsection{Trust and institutions}

Research on interaction between trust as cultural variable and institutions as formal systems has received considerable attention in the economic literature. These studies mainly focus on causal links between trust and institutions based on cross-sectional data, and, as a result, two main concepts are distinguished (Bagrat, Gassner \& Kara, 2017). The first is known as "bottom-up" (psychological) approach when informal rules, beliefs and patterns of behavior influence institutions' development like political system structure, specifics of laws etc. Alesina and Giuliano (2015) present comprehensive overview of the studies and world experience to support empirically this approach. Newton and Zmerli (2011) give empirical evidence of the importance of social trust for political trust.

The second one is the "top" (institutional) approach (reverse of the previous) when structures and institutions can alter social trust. One of the possible channels of influence is experience of interaction with representatives of institutions, and, as a result, perceptions of the trustworthiness and ability to trust others. In other words, institutional quality determines social trust. Sønderskov and Dinesen (2016) in their paper confirmed strong impact of institutional trust on social trust and the latter is likely to change over time under the influence of the institutions. The authors in the papers (Balas et al., 2019; Abaas et al., 2018; Yevdokimov et al., 2018) proved the linking between economic growth, economic freedom, macroeconomic stability and level of trust among society to the institutions in the country.

However, empirical results on correlation between trust and institutions are mixed since there are different forms of institutional trust (Rothstein \& Stolle, 2010) and it is needed to be specified, especially in finance as it based on contractual form of relations and promises about money in the future by these institutions. Secondly, it is more important to understand mechanism and institutional characteristics of interaction and impact between trust and institutions.

\subsection{Interpersonal and institutional trust (trust in banks) interaction}

Trust is the essence of transactions in banking. The precondition for the emergence of the institutional trust concept in banking is the failure of the interpersonal trust mechanism in the conditions of information asymmetry of financial sector and the need to create specialized "expert" institutions to minimize the role of personal relationships. In this case, financial intermediaries (especially banks) are institutions of delegated monitoring and, as a result, institutions of social trust.

Despite massive empirical interest to the issue of trust in banking since the global financial crisis and massive drop in trust in banks, the concept of trust in banks is still undertheorized. Butzbach (2014) in the paper proposes a multidimension comprehensive approach to the trust in banking distinguishing types of trust and their linkages in banking. At the same time, most of the research is concentrated on identification of bank trust determinants like sociodemographic, economic, political and other indicators providing cross-country analysis (Fungácová, Hasan \& Weill, 2016; Jansen \& Mosch \& Cruijsen, 2013; Afandi \& Habibov, 2017). From marketing point of view, bank trust and loyalty determine through competence, stability, integrity, customer orientation, transparency, and value congruence (EsterikPlasmeijer \& Raaij, 2017, Vejačka \& Štofa, 2017, Ercsey, 2017, Szwajca, 2018; Lyulyov et al., 2018). However, some papers empirically prove that individual characteristics have limited power to explain cross-country differences in trust, while country fixed effects have been found to be more significant (Algan \& Cahuc, 2013). 
One of the country fixed effects factor is interpersonal trust that is important condition for forming trust in institutions in general. Finance literature builds on "the contrary (opposite) view" on interaction between interpersonal trust and trust in banks. Initially it means when interpersonal trust does not exist (very low level of generalized trust) in the society then institutional trust (trust in banks on particular) serves as reliable substitute and support for financial contracts. According to Zucker (1986) development of banking as institutions is associated with shift from interpersonal form of trust dominance to institutional when uncertainty is high and only professional institutions (not individuals) could be used for risky investments. Since the 2007-08 crisis, interaction has changed in other direction. Sharp decline of trust in banks and other financial institutions has framed conditions for development of "informal" institutions like bitcoins, peer-to-peer companies etc. and importance of interpersonal trust - trust in other economic agents, not formal institutions.

Sociological literature focuses on "complementary view" on interaction between different types of trust - we can assume positive connection between interpersonal trust and trust in banks. This paper aims to fill the gap between financial and sociological literature towards role of the interpersonal trust in forming trust in banks (Rogowski, 2017). Only a few studies on trust in banks identified positive link between interpersonal trust and trust in banks (Fungácová, Hasan \& Weill, 2016; Mosch \& Prast, 2010) but it is limited evidence on institutional conditions and mechanisms of their interaction.

The empirical application of two concepts are that: interpersonal trust and trust in banks are positively linked (Hypothesis 1). However, the level of the positive influence depends on some conditions (sources of trust) - institutional context (Hypothesis 2).

\section{Methodological approach}

\subsection{Empirical model}

Our methodological approach combines structural modeling and cluster analysis using cross-sectional design. To examine the relationship between social capital (in the form of interpersonal trust) and institutional trust (trust in banks), structural equation model (SEM) technique was used. This statistical instrument provides control of measurement errors by using latent variables in a system of structural equations, and, as a result, better understanding of endogenous variables impacts on exogenous. Moreover, SEM method is especially valuable for research trust as multidimension category as it incorporates observed (measured) and unobserved variables (latent) in equations (Rahmani \& Askari, 2018).

The general model of the estimation equation seeks to assess the impact of a set of factors including interpersonal trust on trust in banks as exogenous variable. The estimation equation is as follow:

$$
\begin{aligned}
& \operatorname{Tr}^{\text {bank' }}=a_{1} * \operatorname{Tr}^{\text {bank }}+\delta_{1} \\
& \operatorname{Tr}^{\text {prs' }}=b_{1} * \operatorname{Tr}^{\text {prs }}+\varepsilon_{1} \\
& \operatorname{Tr}^{\text {bank'}}=c_{1} * \operatorname{Tr}^{\text {prs }}+z_{1}
\end{aligned}
$$

where $\operatorname{Tr}^{\text {bank' }}$ - latent (unobserved) variable to explain trust in banks influenced by actual level of trust in banks and other unaccounted factors; $\operatorname{Tr}^{\text {bank }}$ - actual level of trust in banks; $\mathrm{Tr}^{\text {prs' }}$ - latent (unobserved) variable to explain interpersonal trust influenced by actual level of interpersonal trust and other unaccounted factors; $\operatorname{Tr}^{\text {prs }}$ - actual level of interpersonal trust; 
$\delta_{1}, \varepsilon_{1}, z_{1}-$ constants; $\mathrm{a}_{1}, b_{1}, \mathrm{c}_{1}-$ parameters related to the interaction direction between trust in banks and interpersonal trust.

\subsection{Data}

This paper relies on the data of the World Values Survey extracted from the wave 6 and covering the 2010-2014 - the most recent one. Data were obtained with a sample of 60 countries and more than 85,000 respondents based on nationally representative surveys about trends in beliefs, values and motivations of people throughout the world (Inglehart et al., 2014). The wave 6 for the first time includes the question towards confidence in banks, as a result, it was impossible to use time-series data from the previous waves of the survey in this research.

On the first stage of the analysis, the basic criteria for cross-country analysis of linkages between interpersonal trust and trust in banks was economic development of the country. Huge progress has been made towards empirical evidence on the strong positive connection between interpersonal trust and economic growth (Zak \& Knack, 2001) - it forms foundation for hypothesis that influence of interpersonal trust on trust in banks will be varied depend on economic development of the country. We have selected 50 countries on the World Bank classification grouped in Advanced (1), Emerging and developing (2), CIS countries (3).

After that - on the second step - cluster analysis was utilized to test hypothesis on institutional quality impact on relationships between interpersonal and institutional types of trust. To capture institutional context we use control variables - GDP per capita and GINI index based on the World Bank estimations, and Rule of Law index (from the World Justice Project) as well as Education Index (from the United Nations data). Relationships were analyzed by using Statistica software version 10.0 with the package Advanced methods and Multidimensional analysis package.

\subsection{Measurements}

\section{Interpersonal trust}

The World Values Survey includes traditional indicator of interpersonal trust Rosenberg's question (1957):

V24.- Generally speaking, would you say that most people can be trusted or that you need to be very careful in dealing with people?

To capture the level of trust we take the meaning of indicator for answer "Most people can be trusted".

Trust in banks

The 6 wave of World Values Survey includes indicator on confidence in bank:

V121.- I am going to name a number of organizations. For each one, could you tell me how much confidence you have in them: is it a great deal of confidence, quite a lot of confidence, not very much confidence or none at all?: Banks

To capture the level of trust we take the meaning of indicator for answer "A great deal".

Trust in the courts $\left(\operatorname{Tr}^{\text {crt }}\right)$ and in the government $\left(\operatorname{Tr}^{\text {grvm }}\right)$

Trust in banks and its determinants should be regarded on the basis of institutional theory of social capital. Trust in banks includes confidence not only towards bank as institution 
and provider of bank services, but also confidence in economic environment for decisionmaking in finance. It means for trusting in banks citizens should have positive and fair experience of interaction with governmental authorities. This experience is influenced by performance of justice system towards financial contracts establishment, consumer rights protection and enforcement. Therefore, studying trust in banks it is crucial to take into consideration trustworthiness of government institutions, like trust in courts as one of the market mechanisms for protection financial consumer rights. Citizens interacting institutions (including banks) expect courts to be fair and competent providing equal punishment for breaking rules in financial contracts. Additionally, we include indicator for trust in government - it catches general perception by citizens of public authorities (including banks and banking regulation and supervision bodies) trustworthiness, fair actions and policies (Khalid et al., 2016). According to the World Values Survey these questions have follow formulation:

V114.- I am going to name a number of organizations. For each one, could you tell me how much confidence you have in them: is it a great deal of confidence, quite a lot of confidence, not very much confidence or none at all?: The courts

V115.- I am going to name a number of organizations. For each one, could you tell me how much confidence you have in them: is it a great deal of confidence, quite a lot of confidence, not very much confidence or none at all?: The government

This study explores four control variables as determinants of institutional context for interaction between trust in banks and interpersonal trust.

Education

Education (especially secondary and tertiary) is one of the most relevant sociodemographic trust determinants leading to increase in social trust through experience, socializing activities, skills in handling risks (Helliwell \& Putnam, 2007; Uslaner, 2008). However, recent empirical evidence has found institutional limitations of education impact positive effect on interpersonal trust was recorded only in low-corruption countries (Frederiksen Larsen \& Lolle, 2016). Finance studies point on negative impact of education on trust in banks as economic literacy people are more skeptical on banks (Fungácová, Hasan \& Weill, 2016; Mosch \& Prast, 2010).

In this paper education is defined by the dummy variable equal to education index of the United Nations as part of Human Development Index (calculated using mean years of schooling and expected years of schooling).

GDP per capita

Higher income relates to higher levels of interpersonal trust. Concerning GDP impact on trust in banks empirical results were not significant. Data on GDP per capita are taken from World Bank in constant 2010 U.S. dollars.

Gini index as economic inequality variable

Income variables can significantly influence on trust. Societies with minimal socio-economical gaps generate higher levels of trust (Newton \& Zmerli, 2011; Uslaner, 2008). Data on Gini index are derived from World Bank and measures the extent to which the distribution of income among households within an economy deviates from a perfectly equal distribution.

Rule of Law index

Rule of Law enforcement belongs to strong impact variables of institutional environment and its quality. The legal system is considered to be additional but necessary solution for trustworthiness and transparency ensuring mitigating trust problems. It ranges by World Bank from $-2,5$ to 2,5 .

All control variables are considered as the mean of five years (2010-2014). 


\section{Empirical results and discussion}

\subsection{Descriptive analysis}

Descriptive statistics is shown in the Table 1 and presents a nature of sample variables. The mean value of interpersonal trust is the highest among all analyzed types of trust when trust in institutions is approximately the same and lower than trust to other people. These figures confirm considerable drop of institutional trust after the global financial crisis. According to the Edelman Trust Barometer, which measures trust on a scale of $0-100$, three-quarters of governments around the world are distrusted by their citizens and "...the last decade has seen a loss of faith in traditional authority figures and institutions...". Moreover, relying on Gallup's survey about public confidence in various institutions, declining trust is considered to be from 1995.

Table 1. Descriptive statistics of variables

\begin{tabular}{ccccc}
\hline \multicolumn{1}{c}{ Variable } & Mean & Standard deviation & Minimum & Maximum \\
\hline $\boldsymbol{T r}^{\boldsymbol{p r \boldsymbol { s }}}$ & 23.4 & 15.7 & 3.2 & 66.1 \\
\hline $\boldsymbol{T r}^{\boldsymbol{b a n k}}$ & 15.7 & 10.6 & 1.1 & 45.5 \\
\hline $\boldsymbol{T r}^{\boldsymbol{c r t}}$ & 16.9 & 13.0 & 2.4 & 66.9 \\
\hline $\boldsymbol{T r}^{\boldsymbol{g r v m}}$ & 14.2 & 13.3 & 0.4 & 74.9 \\
\hline GDP per capita & 15596.6 & 17578.5 & 358.4 & 70034.9 \\
\hline GINI index & 37.0 & 8.5 & 24.5 & 63.2 \\
\hline Rule of Law Index & 0.6 & 0.1 & 0.3 & 0.9 \\
\hline Education Index & 0.8 & 0.1 & 0.5 & 0.9 \\
\hline
\end{tabular}

Source: own compilation.

Notes: for the period of 2010-2014

\subsection{Structural equations modeling}

To confirm links between interpersonal trust and trust in banks several structural equation models (SEMs) have been estimated. The received cross-sectional results are reported in the Table 2. SEMs fit indicators were calculated and showed that it is well specified: $\chi^{2}=$ 71.32; $\mathrm{RMSEA}=0,043 ; \mathrm{CFI}=0,993 ; \mathrm{WRMR}=0,912$.

Table 2. SEM results

\begin{tabular}{|c|c|c|c|c|c|c|c|c|c|}
\hline \multirow[t]{2}{*}{ Countries } & \multicolumn{3}{|c|}{$\begin{array}{c}S E M I T r^{\text {prs' }} \\
\text { Tr }^{\text {bank' }}\end{array}$} & \multicolumn{3}{|c|}{$\begin{array}{c}S E M 2 \boldsymbol{T} r^{\text {prs } \prime}+ \\
\operatorname{Tr}^{\text {crt' }} \rightarrow \boldsymbol{T r}^{\text {bank }}\end{array}$} & \multicolumn{3}{|c|}{$\begin{array}{c}\text { SEM3Tr }{ }^{\text {prs } \prime}+\boldsymbol{T r}^{\text {crt' }}+ \\
\operatorname{Tr}^{\text {grvm }} \rightarrow \boldsymbol{T r}^{\text {bank }}{ }^{\prime}\end{array}$} \\
\hline & Est. & Std Er & P-value & Est. & Std Er & P-value & Est. & Std Er & $\mathrm{P}$-value \\
\hline All & 15.13 & 0.002 & 0.497 & 16.87 & 0.004 & 0.231 & 0.50 & 0.031 & 0.451 \\
\hline Advanced & 16.22 & 0.006 & 0.173 & 13.59 & 0.001 & 0.397 & 0.50 & 0.027 & 0.016 \\
\hline $\begin{array}{l}\text { Emerging } \\
\text { and } \\
\text { developing }\end{array}$ & 0.50 & 0.031 & 0.063 & 7.82 & 0.032 & 0.112 & 3.31 & 0.015 & 0.042 \\
\hline CIS & 10.52 & 0.002 & $0.000 * *$ & 6.06 & 0.043 & 0.018 & 0.48 & 0.321 & 0.019 \\
\hline
\end{tabular}

Source: own compilation.

Notes: $* \operatorname{Tr}^{c r t \prime}-$ latent variable of trust in courts; $\operatorname{Tr}^{\text {grvm' }}-$ latent variable of trust in government; $\mathrm{t}-* *$ significant at $1 \%$ ) 
The findings reveal that interpersonal trust has strong positive effect on trust in banks (covariance 10.52) only for CIS countries $(\mathrm{t}=3.52$, for a P-value $<0.05)$. Moreover, results imply that additional variables like trust in courts and government do not influence on linkages between interpersonal trust and trust in banks as they are statistically insignificant. The hypothesis on positive correlation between interpersonal trust and trust in banks is accepted, but provides a rationale for further institutional contexts estimations.

\subsection{Cluster analysis}

Level of economic development may not adequately reflect trust heterogeneity across countries. Using k-means cluster analysis this paper aims to explore influence of institutional conditions on different types trust linkages (Becerra Alonso, D. B. \& Androniceanu, A. \& Georgescu, I., 2016). To capture institutional characteristics variables of GDP per capita, GINI Index, Rule of Law Index, Education Index were used. Based on average scores of these variables four clusters of countries by using Euclidean distance were identified (Table 3).

Table 3. Centroids (central points) of clusters

\begin{tabular}{lcccc}
\hline & Cluster 1 & Cluster 2 & Cluster 3 & Cluster 4 \\
\hline GDP per capita & -0.41 & 1.21 & -0.63 & -0.65 \\
\hline GINI index & 0.72 & -0.58 & -0.75 & 1.58 \\
\hline Rule of Law Index & -0.31 & 1.22 & -0.65 & -0.63 \\
\hline Education Index & -0.02 & 1.18 & -0.32 & -1.33 \\
\hline Number of countries & 17 & 11 & 16 & 6 \\
\hline
\end{tabular}

Source: own compilation.

Notes: based on standardized data

The first cluster is characterized by the low level of economic development and education index, where is high level of inequality in countries (includes countries like Ecuador, Peru, Uruguay). Countries with the highest economic development and education index, the best legal system belong to the second cluster (includes countries like Germany, Poland, Spain). Countries of the third cluster (like India, Belarus, Ukraine) are not good at education and economic development, with the worst among others clusters quality of legal system. Countries of the fourth cluster are outsiders (Ghana, Zimbabwe) with the highest level of inequality, the worst education and the lowest economic development. As it can be seen, clusters present strongly different countries by institutional criteria.

After cluster analysis structural equation modeling was carried out for every identified cluster. Results are presented below:

$$
\begin{aligned}
& \text { Cluster } 1: \operatorname{Tr}^{\text {bank' }}=g_{1} * 15.014 \operatorname{Tr}^{\text {prs }}{ }^{\prime}+\pi_{1} \\
& \text { Cluster 2:Tr } \operatorname{Tr}^{\text {bank' }}=d_{1} * 16.883 \operatorname{Tr}^{p r s^{\prime}}+\alpha_{1} \\
& \text { Cluster } 3: \operatorname{Tr}^{\text {bank' }}=m_{1} * 9.694 \operatorname{Tr}^{p r s^{\prime}}+\mu_{1} \\
& \text { Cluster } 4: \operatorname{Tr}^{\text {bank' }}=n_{1} * 8.350 T r^{p r s^{\prime}}+\beta_{1}
\end{aligned}
$$

The finding indicates that correlations for all clusters are significant (for a P-value < 0.05 ) except the first cluster. The lowest level of linkages between interpersonal trust and trust in banks is revealed for the fourth cluster (the worst institutional environment), the highest level of impact - for the second cluster (the best institutional environment). In this case, second 
hypothesis - "level of the positive influence depends on some conditions (sources of trust) institutional context" is accepted.

\section{Conclusion}

This paper has examined how interpersonal (generalized) trust and institutional - trust in banks - interact. It deals with the issue when trust as informal beliefs/perceptions and determinant of cooperative behavior in the economy can significantly stimulate trust in financial institutions despite the enforcement of legal system or meaningful regulation. Previous researches on trust topic lack consideration of institutional conditions and circumstances for interaction between different types of trust.

The contribution of this paper that it fills the gap between sociological and economic (finance and banking) literature by: 1) providing theoretical framework for interaction informal rules and behavior (interpersonal trust) and formal institutions (trust in banks) on the example of financial system combining micro-approach (psychological) and macro-approach (institutional); 2) focusing not on the causal links but on the co-evolving complement approach to the issue of interaction between trust and institutions taking into account their joint evolution and mutual influence; 3 ) empirical exploring of conditions to better understand mechanism of joint interaction between trust and institutions.

Methodologically relation between social trust and institutional (bank) trust was determined by structural equation modeling and using cross-sectional data from the World Value Survey. Exploring institutional environment by the cluster analysis technique was based on the such variables as education index, GDP per capita, Rule of Law index, GINI as inequality measurement. Empirical results allowed to accept hypothesis on positive linkages between interpersonal trust and trust in banks for all countries. These results are consistent with others in financial recent research on trust issue. However, our paper gives empirical support for accessing the institutional conditions for generating this impact. Identified four clusters of countries with different institutional context provide us with opportunities of positive impact of trust. In economic developed countries with good education, legal system and equal distribution of income, trust impact will be bigger including stronger interpersonal trust impact on institutional trust - trust in banks. This empirical evidence on different types of trust interaction leaves room for government policy and its measures related to ensuring trust for financial, political and macroeconomic stability.

\section{Acknowledgement}

This work would not have been possible without the financial support of the Ministry of Education and Science of Ukraine. The paper was prepared as part of the Young Scientist Research on the topic "Economic-mathematical modeling of the mechanism for restoring public trust in the financial sector: a guarantee for economic security of Ukraine" (registration number 0117U003924). 


\section{References}

Abaas, M. S. M., Chygryn, O., Kubatko, O., \& Pimonenko, T. (2018). Social and economic drivers of national economic development: The case of OPEC countries. Problems and Perspectives in Management, 16(4), 155-168. https://doi.org/10.21511/ppm.16(4).2018.14

Abrhám, J. \& Lžičař, P. (2018). Risk management in the sustainable development: analysis of a selected key industry. Journal of Security and Sustainability Issues, 8(2), 171-180.

Agnihotri, A., Gupta, S. (2019). Relationship of Corporate Governance and Efficiency of Selected Public and Private Sector Banks in India. Business Ethics and Leadership, 3(1), 109-117. http://doi.org/10.21272/bel.3(1). 109-117.2019

Alesina, A. \& Giuliano, P. (2013). "Family Ties," in Handbook of Economic Growth, P. Aghion and S. Durlauf (eds.), North Holland, Elsevier.

Alesina, A. \& Giuliano, P. (2015). Culture and Institutions. Journal of Economic Literature, 53(4), 898-944.

Algan, Y. \& Cahuc, P. (2013). Trust, growth and well-being: new evidence and policy implications. IZA Discussion Papers 7464, Institute for the Study of Labor (IZA).

Andrushkiv, B., Vovk, Y., Pohaydak, O., \& Fedyshyn, I. (2011). Crisis of relationship in general theory of crisis. Journal of International Studies, 4(1), 18-25.

Bagrat, Y., Gassner, L. and Kara, A. (2017). Culture, Institutions, and Economic Performance. Montenegrin Journal of Economics, 13(2), 71-80.

Balas, A.N., Kaya, H.D. (2019). The global economic crisis and retailers' security concerns: The trends. SocioEconomic Challenges, 3(2), 5-14. https://doi.org/10.21272/sec.3(2).514.2019.

Becerra Alonso, D. B. \& Androniceanu, A. \& Georgescu, I. (2016). Sensitivity and vulnerability of European countries in time of crisis based on a new approach to data clustering and curvilinear analysis. Administratie si Management Public, (27), 46-61.

Borum R. (2010). The science of interpersonal trust. The MITRE Corporation. McLean, VA.

Brychko, M.; Semenog, A. (2018) Efficiency as a new ideology of trust-building corporate governance, Business and Economic Horizons, 14(4), 913-925. https://doi.org/10.15208/beh.2018.62

Butzbach, O. (2014). Trust in banks: a tentative conceptual framework. MPRA Paper 53587, University Library of Munich, Germany.

David-Jan Jansen \& Robert Mosch \& Carin van der Cruijsen, (2013). When does the general public lose trust in banks? DNB Working Papers 402, Netherlands Central Bank, Research Department, INNOVATIO Publishing Ltd, Fribourg.

Elvin, A. \& Habibov, N. (2017), Pre- and Post-Crisis Trust in Banks: Lessons from Transitional Countries. Journal of Economic Development, 42, (1), 73-94.

Ercsey I. (2017). The Role of Customers' Involvement in Value Co-creation Behaviour is Value Co-creation the Source of Competitive Advantage? Journal of Competitiveness, 9 (3), 51-66. https://doi.org/10.7441/joc.2017.03.04

Ermisch, J. \& Gambetta, D. (2010). Do strong family ties inhibit trust?. Journal of Economic Behavior and Organisations, 75(3), 365-376.

Fukuyama, F. (1995). Trust: The social virtues and the creation of prosperity. New York: Free Press,

Fungácová, Z., Hasan, I. \& Weill, L. (2016). Trust in Banks. BOFIT Discussion Paper No. 7/2016, Gabelli School of Business, Fordham University Research Paper No. 2782358. https://ssrn.com/abstract=2782358 
Gillespie, N. \& Hurley, R. (2013). Trust and the global financial crisis. Advances in trust research, 177-204.

Guiso, L., Sapienza, P. \& Zingales, L. (2004). The role of social capital in financial development. American Economic Review, 94, 526-556.

Helliwell, J. F. \& Putnam, R. D. (2007). Education and social capital. Eastern Economic Journal, 33(1), 1-19.

Inglehart, R., Haerpfer, C., Moreno, A., Welzel, C., Kizilova, K. et al. (2014). World Values Survey: Round Six - Country-Pooled Datafile Version: www.worldvaluessurvey.org/WVSDocumentationWV6.jsp. Madrid: JD Systems Institute.

Kaasa, A. (2016), Social Capital, Institutional Quality and Productivity: Evidence from European Regions. Economics and Sociology, 9(4), 11-26. https://doi.org/10.14254/2071-789X.2016/9-4/1

Kostel, M., Leus, D., Cebotarenco, A., Mokrushina, A. (2017). The Sustainable Development Goals for Eastern Partnership Countries: Impact of Institutions. SocioEconomic Challenges, 1(3), 79-90. https://doi.org/10.21272sec.1.1(3).79-90.2017

Kowo, Ak.S., Owotutu, S. Ol., \& Adewale Ad. G. (2019). Enhancing the operational effectiveness of savings and credit cooperative societies for sustainable growth. Financial Markets, Institutions and Risks, 3(2), 59-68. http://doi.org/10.21272/fmir.3(2).59-68.2019.

La Porta, R., Lopez-de-Silanes, F., Shleifer, A., \& Vishny, R. (1997). Legal determinants of external finance. Journal of Finance, 52, 1131-1150.

Lazányi, K., \& Bilan, Y. (2017a). Generetion Z on the labour market: do they trust others within their workplace?. Polish Journal of Management Studies, 16, 78-93.

Lazányi, K., Čepel, M., \& Bilan, S. (2017b). Comparison of trust and social relations among students in Russian and Hungarian higher education. Economics \& Sociology, 10(4), 162-174.

Leonov, S., Frolov, S., \& Plastun, V. (2014). Potential of institutional investors and stock market development as an alternative to households' savings allocation in banks. Economic Annals-XXI, (11-12), 65-68.

Levine, R. (2005). Finance and Growth: Theory and Evidence, Handbook of Economic Growth, in: Philippe Aghion \& Steven Durlauf (ed.), Handbook of Economic Growth, edition 1, volume 1 , chapter 12, 865-934.

Lyulyov, O., Chygryn, O., and Pimonenko, T. (2018). National Brand as a Marketing Determinant of Macroeconomic Stability. Marketing and Management of Innovations, 3, 142-152. https://doi.org/10.21272/mmi.2018.3-12

Khalid, M. A., Alam, Md. M., \& Said, J. (2016), Empirical Assessment of Good Governance in the Public Sector of Malaysia. Economics and Sociology, 9(4), 289-304. https://doi.org/10.14254/2071-789X.2016/9-4/18

Morten Frederiksen, Christian A Larsen, \& Henrik L Lolle. (2016). Education and trust: Exploring the association across social relationships and nations. Acta Sociologica, 59(4), 293-308.

Mosch, R. \& Prast, H. (2010). Confidence and trust: empirical investigations for the Netherlands and the financial sector. Beiträge zur Jahrestagung des Vereins für Socialpolitik: Ökonomie der Familie-Session: Trusting Banks in a Financial Crisis, No. A1-V2

Naser, N. (2019). A Comprehensive Analysis of European Banking Soundness - Theoretical Study. Financial Markets, Institutions and Risks, 3(2), 17-43. http://doi.org/10.21272/fmir.3(2).17-43.2019. 
Newton, K., \& Zmerli, S. (2011). Three forms of trust and their association. European Political Science Review, 3(2), 169-200.

Njegovanovic, A. (2018). Neurological aspects of finance, transmitters, emotions, mirror neuronal activity in financial decision. Marketing and Management of Innovations, 3, 186-198. https://doi.org/10.21272/mmi.2018.3-16

Pauline W.J. van Esterik-Plasmeijer, \& van Raaij, W. Fred (2017). Banking system trust, bank trust, and bank loyalty. International Journal of Bank Marketing, 35(1), 97-111.

Prince, T. (2017). Behavioral Finance and the Business Cycle. Business Ethics and Leadership, 1(4), 28-48. https://doi.org/10.21272/bel.1(4).28-48.2017

Prince, T. (2018). Risk management and behavioral finance. Financial Markets, Institutions and Risks, 2(2), 5-21. https://doi.org/10.21272/fmir.2(2).5-21.2018

Rahmani, F., \& Askari, A. (2018). Identifying the effective drivers on internet advertising using structural equation modeling: an empirical investigation. Marketing and Management of Innovations, 2, 351-364. https://doi.org/10.21272/mmi.2018.2-27

Reiersen, J. (2017). Trust as a booster. Journal of Business Economics and Management, 18 (4), 585-598, https://doi.org/10.3846/16111699.2017.1334228

Rogowski, R. (2017). Theoretical Reasons for Economic Sociology. SocioEconomic Challenges, 1(4), 45-49. https://doi.org/10.21272sec.1(4).45-49.2017

Rojek, T. (2019). Analysis of Pro-Market Concept of Business Model. Marketing and Management of Innovations, 2, 266-281. http://doi.org/10.21272/mmi.2019.2-23

Roth, F. (2009), Does too much trust hamper economic growth?. Kyklos, 62(1), 103-128. https://doi.org/10.1111/j.1467-6435.2009.00424.x.

Rothstein, Bo \& Stolle, Dietlind (2010). The State and Social Capital: An Institutional Theory of Generalzed Trust. In Readings in Comparative Politics: Political Challenges and Changing Agendas, edited by Mark Kesselman, 123-28. Boston: Wadsworth Cenage Learning.

Sapienza, P. \& Zingales L. (2012). A trust crisis, International Review of Finance, 12(2), 123 131. https://doi.org/10.1111/j.1468-2443.2012.01152.x.

Simpson J.A. (2007). Foundations of interpersonal trust: A.W. Kruglanski \& E.T. Higgins (Eds.). Social psychology: Handbook of basic principles. New York: Guilford, 2007. 2nd ed.

Sønderskov, K. M. \& Dinesen, P. T. (2016). Trusting the state, trusting each other? The effect of institutional trust on social trust. Political Behavior, 38(1), 179-202. https://doi.org/10.1007/s11109-015-9322-8

Szkudlarek, P., \& Biglieri, J.V. (2016). Trust as an element of social capital - evidence from a survey of Polish and Spanish students. Journal of International Studies, 9(1), 252-264. https://doi.org/10.14254/2071-8330.2016/9-1/19

Szwajca, D. (2018). Relationship between corporate image and corporate reputation in Polish banking sector. Oeconomia Copernicana, 9(3), 493-509. https://doi.org/10.24136/oc.2018.025

Tofan, C. A. (2017). The Process of Communication in Decision-Making. Business Ethics and Leadership, 1(3), 36-44. https://doi.org/10.21272/bel.1(3).36-44.2017

Tonkiss, F. (2009). Trust, confidence and economic crisis. Intereconomics, 44(4), 196-202. https://doi.org/10.1007/s10272-009-0295-x.

Uslaner, E. M. (2008). Corruption, Inequality, and The Rule of Law: The Bulging Pocket Makes the Easy Life, Cambridge University Press, New York.

Vasylieva, T. A., \& Chmutova, I. M. (2015). Empirical model of a bank life cycle. Actual Problems of Economics, 172(10), 352-361. 
Vasylyeva, T. A., Leonov, S. V., \& Lunyakov, O. V. (2014). Countercyclical capital buffer as a macroprudential tool for regulation of the financial sector. Actual Problems of Economics, (8), 278-283.

Veggeland, N. (2018). European economies suffer a crisis of combination. Economics, Management and Sustainability, 3(1), 65-69. https://doi.org/10.14254/jems.2018.3-1.6

Vejačka, M. \& Štofa, T. (2017). Influence of security and trust on electronic banking adoption in Slovakia. E\&M Economics and Management, 20(4), 135-150.

Yevdokimov, Y., Melnyk, L., Lyulyov, O., Panchenko, O., \& Kubatko, V. (2018). Economic freedom and democracy: Determinant factors in increasing macroeconomic stability. Problems and Perspectives in Management, 16(2), 279-290. https://doi.org/10.21511/ppm.16(2).2018.26

Zak, P. J., \& Knack, S. (2001). Trust and Growth. The Economic Journal, 111, 295-321. 